\title{
HUBUNGAN ANTARA KEKUATAN KREDIBILITAS KOMUNIKATOR DALAM KOMUNIKASI INTERPERSONAL DENGAN KEPUASAN PELANGGAN DI RANCAMAYA GOLF DAN COUNTRY CLUB DI KABUPATEN BOGOR
}

\section{RELATIONSHIP BETWEEN STRENGTH CREDIBILITY COMMUNICATORS IN INTERPERSONAL COMMUNICATION WITH CUSTOMER SATISFACTION IN RANCAMAYA GOLF AND COUNTRY CLUB IN DISTRICT OF BOGOR}

\author{
N Nuraeni ${ }^{1}$, Sukarelawati ${ }^{2}$, M Fitriah $^{3 a}$ \\ ${ }^{1}$ Alumni Ps. Ilmu Komunikasi, Fakultas Ilmu Sosial dan Ilmu Politik, Universitas Djuanda Bogor, ${ }^{2}$ Dosen \\ Pembimbing I Program Studi Komunikasi, Fakultas Ilmu Sosial dan Ilmu Politik, ${ }^{3}$ Dosen Pembimbing II \\ Program Studi Komunikasi Universitas Djuanda Bogor, Jl. Tol Ciawi No.1 Kotak Pos 35 Bogor 16720 \\ ${ }^{a}$ Korespondensi: Maria Fitriah, Email: maria_fitriah@yahoo.co.id \\ (Diterima: 07-12-2014; Ditelaah: 10-01-2015; Disetujui: 13-01-2015)
}

\begin{abstract}
This study focused on the relationship of interpersonal communication between golf reservations officer with customers/members during reservation. To Aims of the study was: (1) to determine the strength of the reservation officer's credibility in Rancamaya Golf and Country Club, (2) to determine members/customers satisfaction in Rancamaya Golf and Country Club and (3) to determine the relationship between credibility of the reservation officer's with Rancamaya Golf and Country Club members/customers satisfaction. Type of the research used associative method with a quantitative approach. The results showed that (1) Power of the reservations officer credibility in interpersonal communication was excellent for categories of Ethos, Pathos, Logos, and Competencies. (2) Customer satisfaction rated based on reliability, empathy, and responsiveness was considered very good. (3) Power of the reservations officer credibility interpersonal communication was positive and had specific correlation with customer satisfaction Rancamaya Golf and Country Club, with a correlation of 0.79211 , concluded as the strong category.

Keyword : Power of Communicator Credibility, Customer Satisfaction.
\end{abstract}

\begin{abstract}
ABSTRAK
Penelitian ini memusatkan perhatian pada hubungan komunikasi interpersonal petugas reservasi golf dengan pelanggan pada saat melakukan reservasi. Penelitian ini bertujuan: (1) untuk mengetahui kekuatan kredibilitas petugas reservasi golf di Rancamaya Golf and Country Club, (2) untuk mengetahui kepuasan pelanggan di Rancamaya Golf and Country Club, dan (3) untuk mengetahui hubungan kredibilitas petugas reservasi dengan kepuasan pelanggan Rancamay Golf and Country Club. Jenis penelitian yang digunakan adalah metode asosiatif dengan pendekatan kuantitatif. Hasil penelitian menunjukan bahwa (1) Kekuatan kredibilitas petugas reservasi dalam komunikasi interpersonal untuk kategori ethos, pathos, logos, dan kompetensi termasuk kategori sangat baik. (2) Kepuasan Pelanggan dinilai berdasarkan keandalan, empati, dan daya tanggap dinilai sangat baik. (3) Kekuatan kredibilitas petugas reservasi dalam komunikasi interpersonal berhubungan positifdan signifikasi dengan kepuasan pelanggan Rancamaya Golf and Country Club dengan korelasi sebesar 0,79211, termasuk dalam kategori kuat.

Kata Kunci: Kekuatan Kredibilitas Komunikator, Kepuasan Pelanggan.
\end{abstract}

N Nuraeni dan M Fitriah. 2015. Hubungan Antara Kekuatan Kredibilitas Komunikator Dalam Komunikasi Interpersonal dengan Kepuasan Pelanggan di Rancamaya Golf dan Country Club di Kabupaten Bogor. Jurnal Komunikatio 1(1): 1-15. 


\section{PENDAHULUAN}

Produk atau jasa yang bersaing dalam satu pasar semakin banyak dan beragam. Persaingan antar produsen untuk dapat memenuhi kebutuhan konsumen serta memberikan kepuasan kepada pelanggan secara maksimal terjadi akibat keterbukaan pasar karena pada dasarnya tujuan dari suatu bisnis adalah untuk menciptakan rasa puas pada pelanggan. Salah satu tindakan untuk memuaskan konsumen adalah dengan cara memberikan pelayanan kepada konsumen dengan sebaik-baiknya. Ada beberapa hal yang dapat memberikan kepuasan pelanggan yaitu nilai total pelanggan yang terdiri dari nilai produk, nilai pelayanan pelanggan yang terdiri dari biaya moneter, biaya waktu, biaya tenaga, dan biaya pikiran (Kotler,2000).

Menurut Tjiptono (2004) adanya kualitas pelayanan yang baik di dalam suatu perusahaan akan menciptakan kepuasan bagi para konsumennya. Kepuasan pelanggan menurut Thibault dan Kelley dalam Tjiptono (2004) menyatakan bahwa kepuasan kita akan suatu hubungan yang berakar dari membandingkan penghargaan dan pengorbanan yang ada dalam hubungan itu dengan standar bagian apa yang dianggap seseorang harus ia dapatkan dalam suatu hubungan.

Interaksi antara pelayan dengan pelanggan terjadi pada saat proses pelayanan langsung terhadap pelanggan. Interaksi terjadi melalui kontak komunikasi pelayan yang harus memiliki kredibilitas komunikasi. Komunikasi yang terjadi merupakan kontak langsung secara tatap muka (face to face) sehingga komunikasi ini dinamakan proses komunikasi interpersonal.

Hovlan dalam Venus (2004) menemukan tiga aspek yang memengaruhi kredibilitas sumber, yaitu keterpercayaan (trust worthiness), keahlian (expertise), dan daya tarik (attractiveness).

Berdasarkan latar belakang yang telah diuraikan di atas, maka rumusan penelitian ini adalah sebagai berikut: (1) Bagaimana kekuatan kredibilitas petugas reservasi di Rancamaya Golf and Country Club?, (2) Bagaimana Kepuasan Pelanggan di Rancamaya Golf and Country Club ? (3) Bagaimana hubungan antara kekuatan kredibilitas petugas reservasi golf dengan kepuasan pelanggan golf di Rancamaya Golf and Country Club?.
Tujuan Penelitian ini bertujuan untuk: (1) Mengetahui kekuatan kredibilitas petugas reservasi golf di Rancamaya Golf and Country Club. (2) Mengetahui kepuasan pelanggan di Rancamaya Golf \& Country Club. (3) Mengetahui hubungan antara kekuatan kredibilitas petugas reservasi golf dalam komunikasi interpersonal dengan kepuasan pelanggan golf di Rancamaya Golf and Country Club. Adapun manfaat Penelitian adalah : (1) Manfaat Teoritis Penelitian ini merupakan sarana pengetahuan dan praktek dalam proses penelitian tentang hubungan antara kekuatan kredibilitas petugas reservasi golf dalam komunikasi interpersonal dengan kepuasan pelanggan di Rancamaya Golf and Country Club. (2) Manfaat praktis dapat menjadi bahan studi dan evaluasi bagi perusahaan untuk melakukan perbaikan, khususnya bagian petugas reservasi sehingga dapat memberikan pelayanan yang prima melalui informasi yang lengkap bagi pelanggan dalam mencapai kepuasan pelayanan produk jasa perusahaan golf.

\section{Kerangka Pemikiran}

Peranan layanan terhadap pelanggan dalam usahanya untuk dapat memenuhi kepuasan konsumen sangat penting. Hasibuan (2001) berpendapat bahwa pelayanan adalah kegiatan pemberian jasa dari satu pihak kepada pihak lainnya, di mana pelayanan yang baik adalah pelayanan yang dilakukan secara ramah tamah dan dengan etika yang baik sehingga memenuhi kebutuhan dan kepuasan bagi yang menerima. Sedangkan menurut Tjiptono (2006), pelayanan prima adalah pelayanan yang sangat baik dan melampaui harapan pelanggan sehingga dapat memuaskan para pelanggannya secara lebih baik yang pada gilirannya dapat menumbuhkan loyalitas pelanggan sehingga terjadi pembelian ulang.

Wells dan Prensky (1996) mendefinisikan bahwa kepuasan atau ketidakpuasan merupakan suatu sikap konsumen terhadap produk dan jasa sebagai hasil dari evaluasi konsumen berdasarkan pengalaman konsumen setelah menggunakan sebuah produk atau jasa. Menurut Aristoteles dalam Cangara (2007), komunikator harus memiliki kredibilitas untuk memberikan kepuasan kepada pelanggan di antaranya ethos. pathos (emosional), dan Logos (logika). Sementara Kotler

(2000) 
mengungkapkan faktor tingkat kepuasan meliputi keandalan (reliability), daya tanggap (responsiveness), kepastian (assurance), empati (empathy), dan wujud Fisik (tangible).

Sesuai dengan kerangka pikir sebagaimana dapat dilihat pada gambar 1, kredibilitas komunikator (X) yang merupakan variabel bebas dianalisis dengan mempergunakan kategori-kategori yaitu ethos $\left(\mathrm{X}_{1}\right)$, pathos $\left(\mathrm{X}_{2}\right)$, logos $\left(\mathrm{X}_{3}\right)$, dan kompetensi $\left(\mathrm{X}_{4}\right)$. Kepuasan pelanggan $(\mathrm{Y})$ yang merupakan variabel terikat dianalisis dengan mempergunakan kategorikategori yang terdiri dari keandalan $\left(\mathrm{Y}_{1}\right)$, empati $\left(\mathrm{Y}_{2}\right)$, dan daya tanggap $\left(\mathrm{Y}_{3}\right)$ dari petugas reservasi. Kategori Keandalan $\left(\mathrm{Y}_{1}\right)$ merupakan kemampuan petugas reservasi dalam memberikan pelayanan jasa yang tepat dan yang telah dijanjikan dengan segera, akurat serta memuaskan dengan indikator memberikan pemecahan masalah yang dihadapi oleh pelanggan dengan segera memberikan pelayanan sesuai janji. Kategori Empati $\left(\mathrm{Y}_{2}\right)$ yang merupakan kemampuan petugas reservasi untuk melakukan hubungan komunikasi yang baik serta memahami kebutuhan pelanggan memiliki indikator memberikan penuh kepada pelanggan dan memahami karakterisik pelanggan. Untuk kategori Daya Tanggap $\left(\mathrm{Y}_{3}\right)$ yang merupakan kesigapan petugas reservasi dalam memberikan pelayanan serta membantu pelanggan dengan cepat dan segera terdiri dari indikator pelayanan yang cepat dan tanggap dalam melayani pelanggan.

Gambar 1. Hubungan Antara Kekuatan Kredibilitas Komunikatordalam KomunikasiInterpersonaldengan Kepuasam Pelanggan di Rancamaya Golf and Country Club

\section{Kredibilitas Komunikator (Petugas \\ Reservasi Golf) dalam komunikasi Interpersonal}

\begin{tabular}{l}
$\mathrm{X}_{1}$ Ethos \\
$\mathrm{X}_{2}$ Pathos \\
$\mathrm{X}_{3}$ Logos \\
$\mathrm{X}_{4}$ Kompetensi \\
\hline
\end{tabular}

\section{Y. Kepuasan Pelanggan}

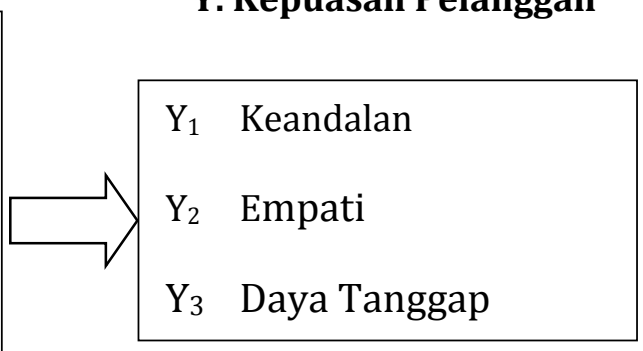


Adapun hipotesis dalam penelitian ini adalah:

$\mathrm{H}_{\mathrm{a}}=$ Terdapat hubungan yang erat antara Kekuatan kredibilitas Komunikator (Petugas Reservasi Golf) dengan kepuasan pelanggan golf di Rancamaya Golf and Country Club.

$\mathrm{H}_{0}=$ Tidak terdapat hubungan yang erat antara Kekuatan kredibilitas Komunikator (Petugas Reservasi Golf) dengan kepuasan pelanggan golf di Rancamaya Golf and Country Club.

\section{MATERI DAN METODE}

Pendekatan dalam penelitian ini adalah pendekatan kuantitatif. Penelitian ini menggunakan metode asosiatif dengan pendekatan kuantitatif. Artinya penelitian yang menguji hubungan antara variabel kekuatan kredibilitas petugas reservasi golf dalam komunikasi interpersonal (variabel X) dan tingkat kepuasan pelanggan (variabel $Y$ ). Penelitian dilakukan pada di Rancamaya Golf and Country Club yang beralamat di Jalan Raya Sukabumi No. 1, Ciawi - Bogor pada tanggal 2 Mei sampai 15 Juni 2014.

Populasi dalam penelitian ini adalah pelanggan di Rancamaya Golf and Country Club, diambil dari rata-rata yang datang bermain golf pada hari Sabtu yaitu 134 orang. Sampel dalam penelitian ini sebanyak 100 responden. Penentuan sampel dalam penelitian ini menggunakan teknik sampling yaitu random sampling. Dalam menentukan jumlah sampel dihitung berdasarkan rumus Slovin sebagai berikut :

$$
n=\frac{N}{1+N(e)^{2}}
$$

Keterangan : $\mathrm{n}$ =besar sampel, $\mathrm{N}=$ besar populasi, $\mathrm{E}=\%$ kelonggaran ketidaktelitian karena kesalahan pengambilan sampel yang masih dapat ditolerir (batas kesalahan $\pm 5 \%$ ). Teknik pengambilan data pada penelitian ini dilakukan melalui data primer yang meliputi observasi langsung dan kuesioner. Sedangkan data sekunder meliputi artikel, internet, dan dokumen-dokumen. Data dalam penelitian ini dianalisis dengan menggunakan beberapa prosedur statistik. Stanford Labovits Research dalam Siregar (1993) digunakan untuk mengemukakan dan memperoleh angka penafsiran dipergunakan rumus :

$$
M=\sum f(x) / n
$$

Keterangan: $\mathrm{M}=$ perolehan angka kriteria penafsiran, $\mathrm{f}=$ frekuensi jawaban, $\mathrm{x}=$ pembobotan (skala nilai) $\sum$ = Penjumlahan, $\mathrm{n}=$ Jumlah sampel penelitian.

Berdasarkan pada jenis data yaitu data ordinal serta sifat penelitian yang merupakan korelasi ini, maka untuk mengukur hubungan antar variabel dipergunakan rumus statistik koefisien korelasi tata jentang Spearman dan kemungkinan besar ada nilai yang sama atau kembar(Sugiyono, 2000).

Adapun rumusnya adalah sebagai berikut:

$r s=\frac{\sum x^{2}+\sum y^{2}-\sum d i^{2}}{2 \sqrt{\left(\sum x^{2}\right)\left(\sum y^{2}\right)}}$

Nilai $\sum x^{2}$ dihitung dengan mempergunakan rumus: $\sum \mathrm{X}^{2}=\frac{N^{\mathrm{s}}-N}{12}-\sum t_{x}$

Di mana $\sum t x=\frac{t^{1}-t}{12}$

Nilai $\sum y^{2}$ dihitung dengan mempergunakan rumus: $\sum \mathrm{y}^{2}=\frac{N^{\mathrm{g}}-N}{12}-\sum t_{y}$

Di mana $\sum t y=\frac{t^{\mathrm{s}}-t}{12}$

Selanjutnya, nilai di dihitung dengan

mempergunakan rumus:

$d i=R_{x}-R_{y}$

Keterangan:

$\mathrm{r}=$ Koefisien korelasi Spearman, $\mathrm{X}=$ Variabel Kredibilitas Komunikator,

$\mathrm{Y}=$ Variabel Kepuasan Pelanggan, $\mathrm{di}^{2}=$ Kuadrat Selisih nilai $X$ dan nilai $Y$,

$\mathrm{n}=$ banyaknya responden, $\mathrm{T}_{\mathrm{x}}=$ Jenjang kembar variabel $\mathrm{X}, \mathrm{T}_{\mathrm{y}}=$ Jenjang kembar variabel $\mathrm{Y}$

Responden dalam penelitian ini berjumlah 100 , maka untuk menguji apakah hubungan antara variabel tersebut digunakan uji signifikan dengan rumus sebagai berikut:

$t=r s \sqrt{\frac{N-2}{1-r_{s}^{2}}}$ 
Kemudian hasil perhitungan $\mathrm{t}$ tersebut akan dikonsultasikan dengan tabel $\mathrm{F}$ (batas nilainilai kritis t) dengan tingkat kepercayaan 95\% atau taraf signifikasinya 0,05 dan derajat kebebasan (df) $=98 \quad(\mathrm{~N}-2)$. Kriteria pengujiannya adalah apabila nilai $t$ hitung $>t$ tabel, maka pernyataan dinyatakan valid, dan sebaliknya apabila nilai $\mathrm{t}$ hitung $<\mathrm{t}$ tabel, maka pernyataan dinyatakan tidak valid.

Penafsiran terhadap keeratan hubungan antar variabel kredibilitas komunikasi interpersonal komunikator petugas reservasi golf (variabel $\mathrm{X}$ ) dengan kepuasan pelanggan (variabel Y) berpatokan pada pedoman interpretasi koefisien korelasi disampaikan pada tabel berikut.

\section{Pedoman Interval Koefisien Tingkat} Hubungan

\begin{tabular}{ll}
\hline Sangat Rendah & $0,199-0,00$ \\
Rendah & $0,399-0,20$ \\
Sedang & $0,599-0,40$ \\
Kuat & $0,799-0,60$ \\
Sangat Kuat & $1,000-0,80$ \\
\hline
\end{tabular}

Hasil rho hitung tersebut, yaitu hasil koefisien Korelasi Rank Spearman $\left(r_{s}\right)$ kemudian dikonsultasikan dengan rho tabel untuk menyatakan menerima atau menolak hipotesa nol $\left(\mathrm{H}_{0}\right)$ berdasarkan kaidah pengambilan kesimpulan.

Selanjutnya untuk digambarkan daerah penerimaan/penolakan hipotesa nol $\left(\mathrm{H}_{0}\right)$ secara dua pihak. Penentuan besaran sumbangan (Kontribusi) Kredibilitas Petugas Reservasi pada kategori dapat dipercaya dan ahli dibidangnya dengan Kepuasan Pelanggan (Y) dihitung dengan mempergunakan rumus koefisien Determinasi (Kd) sebagai berikut:

$$
\mathrm{Kd}=\mathrm{rs}^{2} \times 100 \%
$$

\section{HASIL DAN PEMBAHASAN}

\section{Analisis Data Responden}

Responden dalam penelitian ini adalah Pelanggan di Rancamaya Golf and Country Club. Dalam penelitian ini, responden dianalisis berdasarkan jenis kelamin, usia, pendidikan, pekerjaan dan lamanya menjadi pelanggan (Tabel 1). 
Tabel 1. Jumlah dan Prosentase Responden Menurut Jenis Kelamin, Usia, Pendidikan, Pekerjaan dan Lamanya Menjadi Pelanggan

\begin{tabular}{llcc}
\hline & Karekteristik Responden & Jumlah & Prosentase \\
\hline \multirow{2}{*}{ Jenis Kelamin } & Laki-laki & 88 & $88 \%$ \\
& Perempuan & 12 & $12 \%$ \\
\hline \multirow{2}{*}{ Usia } & $21-30$ tahun & 2 & $2 \%$ \\
& $31-40$ tahun & 15 & $15 \%$ \\
& $41-50$ tahun & 51 & $51 \%$ \\
& $>50$ tahun & 32 & $32 \%$ \\
\hline Pendidikan & SMA & 5 & $5 \%$ \\
& Perguruan Tinggi & 95 & $95 \%$ \\
\hline Pekerjaan & PNS & 6 & $6 \%$ \\
& TNI/Polri & 17 & $17 \%$ \\
& Pegawai Swasta & 21 & $21 \%$ \\
& Pengusaha/Wiraswasta & 52 & $52 \%$ \\
& Lainnya & 4 & $4 \%$ \\
\hline Lama menjadi & $<1$ tahun & 0 & $0 \%$ \\
pelanggan & $1-5$ tahun & 15 & $15 \%$ \\
& $6-10$ tahun & 27 & $27 \%$ \\
& $10-15$ tahun & 55 & $55 \%$ \\
\hline
\end{tabular}

Sumber: Hasil Penelitian 2014

Berdasarkan tabel 5.1, pelanggan golf di Rancamaya Golf and Country Club didominasi oleh kaum Pria (88\%). Sedangkan untuk tingkat usia didominasi oleh pelanggan yang berusia 41 sampai 50 tahun sebanyak 51 responden (51\%). Latar belakang pendidikan pelanggan sebagian besar adalah Perguruan Tinggi sebanyak 95 responden (95\%) dengan latar belakang pekerjaan sebagai pengusaha/Wiraswasta sebanyak 52 responden (52\%). Sedangkan untuk lamanya menjadi pelanggan terbanyak adalah telah menjadi pelanggan selama 10 sampai 15 tahun adalah sebanyak 55 responden (55\%). Hal tersebut dapat diartikan bahwa pelanggan di
Rancamaya Golf and Country Club memiliki segmentasi untuk kalangan menengah keatas dengan latar belakang ekonomi yang berada dalam kondisi mapan. Olahraga golf merupakan olahraga yang seringkali dijadikan sebagai salah satu sarana bagi para pelaku bisnis untuk melakukan kesepakatan dan negosiasi tertentu bagi usaha mereka.

\section{Kredibilitas Komunikator (Petugas Reservasi Golf)}

Berikut tanggapan responden terhadap kredibilitas petugas reservasi sebagai komunikator dapat dilihat pada Tabel 2.

Tabel 2. Tanggapan Responden tentang Variabel Ethos

\begin{tabular}{|c|c|c|c|c|c|c|c|c|c|}
\hline \multirow[t]{2}{*}{ No. } & \multirow[t]{2}{*}{ Indikator } & \multicolumn{5}{|c|}{ Frekuensi (f) } & \multirow[t]{2}{*}{$\mathrm{F}(\mathrm{x})$} & \multirow[t]{2}{*}{$\sum \mathrm{f}(\mathrm{x}) / \mathrm{n}$} & \multirow[t]{2}{*}{ Kriteria } \\
\hline & & SS & $\mathrm{S}$ & $\mathrm{R}$ & TS & STS & & & \\
\hline 1 & $\begin{array}{l}\text { Mendapatkan informasi yang } \\
\text { lengkap dan terperinci }\end{array}$ & 80 & 20 & 0 & 0 & 0 & 480 & 4,8 & $\begin{array}{l}\text { Sangat } \\
\text { Baik }\end{array}$ \\
\hline 2 & $\begin{array}{l}\text { Mendapatkan informasi yang } \\
\text { jelas }\end{array}$ & 66 & 34 & 0 & 0 & 0 & 466 & 4,66 & $\begin{array}{l}\text { Sangat } \\
\text { Baik }\end{array}$ \\
\hline 3 & $\begin{array}{l}\text { Informasi yang diterima } \\
\text { sesuai dengan kenyataan yang } \\
\text { ada. }\end{array}$ & 64 & 36 & 0 & 0 & 0 & 464 & 4,64 & $\begin{array}{l}\text { Sangat } \\
\text { Baik }\end{array}$ \\
\hline 4 & $\begin{array}{l}\text { Percaya dengan Informasi } \\
\text { yang disampaikan oleh }\end{array}$ & 67 & 33 & 0 & 0 & 0 & 467 & 4,67 & $\begin{array}{l}\text { Sangat } \\
\text { Baik }\end{array}$ \\
\hline
\end{tabular}




\begin{tabular}{|l|l|l|l|l|l|l|l|l|l|}
\hline & Petugas Reservasi & & & & & & & \\
\hline 5 & $\begin{array}{l}\text { Petugas Reservasi memiliki } \\
\text { pengetahuan yang cukup } \\
\text { tentang Golf Rancamaya }\end{array}$ & 63 & 37 & 0 & 0 & 0 & 463 & 4,63 & $\begin{array}{l}\text { Sangat } \\
\text { Baik }\end{array}$ \\
\hline Jumlah Angka Penafsiran & & & 4,68 & $\begin{array}{l}\text { Sangat } \\
\text { Baik }\end{array}$ \\
\hline
\end{tabular}

Sumber: Hasil penelitian 2014

Berdasarkan hasil penelitian mayoritas responden sebanyak 80 responden (80\%) menyatakan sangat setuju mendapatkan informasi yang lengkap dan terperinci. Hal ini dibuktikan dengan angka penafsiran yang diperoleh sebesar 4,8 dan berada pada kriteria sangat baik. Sesuai dengan pernyataan Aristoteles dalam Cangara (2007),
Komunikator dapat meyakinkan sasaran dalam menginformasikan pesan kepada komunikan.

Selanjutnya, untuk mengetahui petugas reservasi yang memiliki Pathos selama berinteraksi dengan pelanggan pada saat melakukan reservasi, berikut ini dapat diketahui dalam Tabel 3 berikut.

Tabel 3. Tanggapan Responden tentang Variabel Pathos

\begin{tabular}{|c|c|c|c|c|c|c|c|c|c|}
\hline \multirow{2}{*}{ No } & \multirow{2}{*}{ Indikator } & \multicolumn{5}{|c|}{ Frekuensi (f) } & \multirow{2}{*}{$\mathrm{F}(\mathrm{x})$} & \multirow{2}{*}{$\sum \mathrm{f}(\mathrm{x}) / \mathrm{n}$} & \multirow{2}{*}{ Kriteria } \\
\hline & & SS & $S$ & $\mathrm{R}$ & TS & STS & & & \\
\hline 1 & $\begin{array}{l}\text { Memperoleh solusi yang baik } \\
\text { dari petugas reservasi }\end{array}$ & 94 & 6 & 0 & 0 & 0 & 494 & 4,94 & $\begin{array}{l}\text { Sangat } \\
\text { Baik }\end{array}$ \\
\hline 2 & $\begin{array}{l}\text { Petugas reservasi mampu } \\
\text { mengendalikan emosi } \\
\text { responden dengan baik }\end{array}$ & 93 & 7 & 0 & 0 & 0 & 493 & 4,93 & $\begin{array}{l}\text { Sangat } \\
\text { Baik }\end{array}$ \\
\hline 3 & $\begin{array}{l}\text { Senang berinteraksi dengan } \\
\text { petugas reservasi }\end{array}$ & 93 & 7 & 0 & 0 & 0 & 493 & 4,93 & $\begin{array}{l}\text { Sangat } \\
\text { Baik }\end{array}$ \\
\hline 4 & $\begin{array}{l}\text { Petugas reservasi memiliki } \\
\text { ahlak yang baik dan sopan } \\
\text { dalam berbicara }\end{array}$ & 86 & 12 & 0 & 0 & 0 & 486 & 4,86 & $\begin{array}{l}\text { Sangat } \\
\text { Baik }\end{array}$ \\
\hline 5 & $\begin{array}{l}\text { Semangat dalam } \\
\text { mendapat informasi program } \\
\text { golf yang inovatif }\end{array}$ & 89 & 11 & 0 & 0 & 0 & 489 & 4,89 & $\begin{array}{l}\text { Sangat } \\
\text { Baik }\end{array}$ \\
\hline \multicolumn{7}{|c|}{ Jumlah Angka Penafsiran } & \multicolumn{2}{|c|}{24,53} & \\
\hline \multicolumn{7}{|c|}{ Rata-rata angka penafsiran } & \multicolumn{2}{|c|}{4,906} & $\begin{array}{l}\text { Sangat } \\
\text { Baik }\end{array}$ \\
\hline
\end{tabular}

Sumber: Hasil penelitian 2014

Berdasarkan hasil penelitian mayoritas responden sebanyak 94 responden (94\%) menyatakan sangat setuju memperoleh solusi yang baik dari petugas reservasi. Hal ini 
dibuktikan dengan angka penafsiran yang diperoleh sebesar 4,94 dan berada pada kriteria sangat baik. Sesuai demham pendapat Aristoteles dalam Cangara (2007), komunikator dapat memberikan solusi bagi komunikan dalam memcahkan masalah dengan cara yang baik dan tepat.

Petugas reservasi telah mampu mempengaruhi pelanggan dengan mempergunakan daya tarik emosional yang baik. Artinya petugas reservasi mampu memberikan pelayanan termasuk mampu untuk memecahkan masalah yang dihadapi oleh pelanggan dalam melakukan resevasi dengan mempergunakan yang baik dan tepat.

Selanjutnya, untuk mengetahui petugas reservasi yang memiliki Logos selama berinteraksi dengan pelanggan pada saat melakukan reservasi dari variabel berkomunikasi secara interaktif, menimbulkan keyakinan kepada pelanggan atas informasi yang diberikan, pelayanan yang cepat dan cekatan, pemberian argumen yang baik dan pakaian rapi, bersih serta menarik yang diajukan kepada responden melalui kuesioner yang hasilnya dalam tabel sebagai berikut.

Tabel 4. Tanggapan Responden tentang Variabel Logos

\begin{tabular}{|c|c|c|c|c|c|c|c|c|c|}
\hline \multirow{2}{*}{ No } & \multirow{2}{*}{ Indikator } & \multicolumn{5}{|c|}{ Frekuensi (f) } & \multirow{2}{*}{$\mathrm{F}(\mathrm{x})$} & \multirow{2}{*}{$\sum \mathrm{f}(\mathrm{x}) / \mathrm{n}$} & \multirow{2}{*}{ Kriteria } \\
\hline & & SS & $\mathrm{S}$ & $\mathrm{R}$ & TS & STS & & & \\
\hline 1 & $\begin{array}{l}\text { Petugas Reservasi } \\
\text { berkomunikasi secara aktif } \\
\text { ketika menyampaikan } \\
\text { informasi }\end{array}$ & 85 & 15 & 0 & 0 & 0 & 425 & 4,85 & $\begin{array}{l}\text { Sangat } \\
\text { Baik }\end{array}$ \\
\hline 2 & $\begin{array}{l}\text { Yakin dengan informasi yang } \\
\text { disampaikan Petugas } \\
\text { Reservasi }\end{array}$ & 77 & 23 & 0 & 0 & 0 & 477 & 4,77 & $\begin{array}{l}\text { Sangat } \\
\text { Baik }\end{array}$ \\
\hline 3 & $\begin{array}{l}\text { Pelayanan yang cepat dan } \\
\text { cekatan }\end{array}$ & 77 & 23 & 0 & 0 & 0 & 477 & 4,77 & $\begin{array}{l}\text { Sangat } \\
\text { Baik }\end{array}$ \\
\hline 4 & $\begin{array}{l}\text { Petugas Reservasi } \\
\text { memberikan argumentasi } \\
\text { yang baik dalam menjawab } \\
\text { pertanyaan }\end{array}$ & 85 & 15 & 0 & 0 & 0 & 485 & 4,85 & $\begin{array}{l}\text { Sangat } \\
\text { Baik }\end{array}$ \\
\hline 5 & $\begin{array}{l}\text { Petugas Reservasi } \\
\text { berpakaian rapi, bersih dan } \\
\text { menarik pada saat } \\
\text { berinteraksi dengan } \\
\text { responden }\end{array}$ & 83 & 17 & 0 & 0 & 0 & 483 & 4,83 & $\begin{array}{l}\text { Sangat } \\
\text { Baik }\end{array}$ \\
\hline \multicolumn{7}{|c|}{ Jumlah Angka Penafsiran } & \multicolumn{2}{|c|}{24,07} & \\
\hline \multicolumn{2}{|c|}{ Rata-rata angka penafsiran } & & & & & & \multicolumn{2}{|c|}{4,814} & $\begin{array}{l}\text { Sangat } \\
\text { Baik }\end{array}$ \\
\hline
\end{tabular}

Sumber: Hasil penelitian 2014 
Berdasarkan hasil penelitian, mayoritas responden sebanyak 85 responden (85\%) menyatakan sangat setuju petugas reservasi berkomunikasi secara aktif ketika menyampaikan informasi dan petugas reservasi memberikan argumentasi yang baik dalam menjawab pertanyaan dari responden. Hal ini dibuktikan dengan angka penafsiran yang diperoleh sebesar 4,85 dan berada pada kategori sangat baik. Sebagaimana pernyataan yang disampaikan oleh Aristoteles dalam Cangara (2007), komunikator selalu dapat memberikan keyakinan dan mampu bertindak secara cepat.
Petugas reservasi mampu memberikan alasan kepada responden dengan cara memberikan bujukan yang mempergunakan penalaran yang baik. Artinya petugas reeservai mampu menimbulkan keyakinan dan mampu bertindak dengan cepat. Petugas reservasi juga memiliki Kompetensi selama berinteraksi dengan pelanggan pada saat melakukan reservasi dari indikator memberikan solusi, mengendalikan emosi pelanggan, menimbulkan rasa senang ketika berinteraksi, ahlak yang baik serta sopan dalam berbicara dan informasi yang inovatif yang diajukan kepada responden melalui kuesioner yang hasilnya dalam Tabel 5 sebagai berikut.

Tabel 5. Tanggapan Responden tentang Variabel Kompetensi

\begin{tabular}{|c|c|c|c|c|c|c|c|c|c|}
\hline \multirow{2}{*}{ No } & \multirow{2}{*}{ Indikator } & \multicolumn{5}{|c|}{ Frekuensi (f) } & \multirow{2}{*}{$\mathrm{F}(\mathrm{x})$} & \multirow{2}{*}{$\sum \mathrm{f}(\mathrm{x}) / \mathrm{n}$} & \multirow{2}{*}{ Kriteria } \\
\hline & & SS & $\mathrm{S}$ & $\mathrm{R}$ & TS & STS & & & \\
\hline 1 & $\begin{array}{l}\text { Petugas Reservasi } \\
\text { mempergunakan bahasa yang } \\
\text { sederhana dalam menjelaskan } \\
\text { informasi }\end{array}$ & 84 & 16 & 0 & 0 & 0 & 484 & 4,84 & $\begin{array}{l}\text { Sangat } \\
\text { Baik }\end{array}$ \\
\hline 2 & $\begin{array}{l}\text { Mengerti dengan Informasi } \\
\text { yang disampaikan oleh Petugas } \\
\text { Reservasi }\end{array}$ & 84 & 16 & 0 & 0 & 0 & 484 & 4,84 & $\begin{array}{l}\text { Sangat } \\
\text { Baik }\end{array}$ \\
\hline 3 & $\begin{array}{l}\text { Petugas Reservasi dapat } \\
\text { menjelaskan istilah asing } \\
\text { dalam dunia golf dengan benar }\end{array}$ & 90 & 10 & 0 & 0 & 0 & 490 & 4,9 & $\begin{array}{l}\text { Sangat } \\
\text { Baik }\end{array}$ \\
\hline 4 & $\begin{array}{l}\text { Petugas Reservasi dapat } \\
\text { menyelesaikan masalah }\end{array}$ & 91 & 9 & 0 & 0 & 0 & 491 & 4,91 & $\begin{array}{l}\text { Sangat } \\
\text { Baik }\end{array}$ \\
\hline 5 & $\begin{array}{l}\text { Petugas Reservasi } \\
\text { menyampaikan informasi } \\
\text { dengan penuh percaya diri }\end{array}$ & 96 & 4 & 0 & 0 & 0 & 496 & 4,96 & $\begin{array}{l}\text { Sangat } \\
\text { Baik }\end{array}$ \\
\hline \multicolumn{7}{|c|}{ Jumlah Angka Penafsiran } & \multicolumn{2}{|c|}{24,47} & \\
\hline \multicolumn{7}{|c|}{ Rata-rata angka penafsiran } & \multicolumn{2}{|c|}{4,89} & $\begin{array}{l}\text { Sangat } \\
\text { Baik }\end{array}$ \\
\hline
\end{tabular}

Sumber: Hasil penelitian 2014 
Berdasarkan hasil penelitian, mayoritas responden sebanyak 96 responden (96\%) menyatakan sangat setuju petugas reservasi menyampaikan informasi dengan penuh percaya diri. Hal ini dibuktikan dengan angka penafsiran yang diperoleh sebesar 4,96 dan berada pada kriteria sangat baik. Sesuai dengan pernyataan McCroskey dalam Cangara (2007), komunikator menguasai masalah yang dihadapi dan dibahasnya.

\section{Kepuasan Pelanggan Rancamaya Golf and Country Club}

Kepuasan pelanggan sebagai suatu sikap konsumen terhadap produk dan jasa sebagai hasil dari evaluasi konsumen berdasarkan pengalaman konsumen setelah menggunakan sebuah produk atau jasa. Konsumen merasa puas jika pelayanan yang diberikan dari produk dan jasa menyenangkan hati pelanggan (Wells dan Prensky, 1996). Menurut Kotler (2000), faktor penentu kepuasan pelanggan di antaranya adalah keandalan, empati dan daya tanggap (Tabel 6).

Tabel 6. Tanggapan Responden tentang Variabel Keandalan

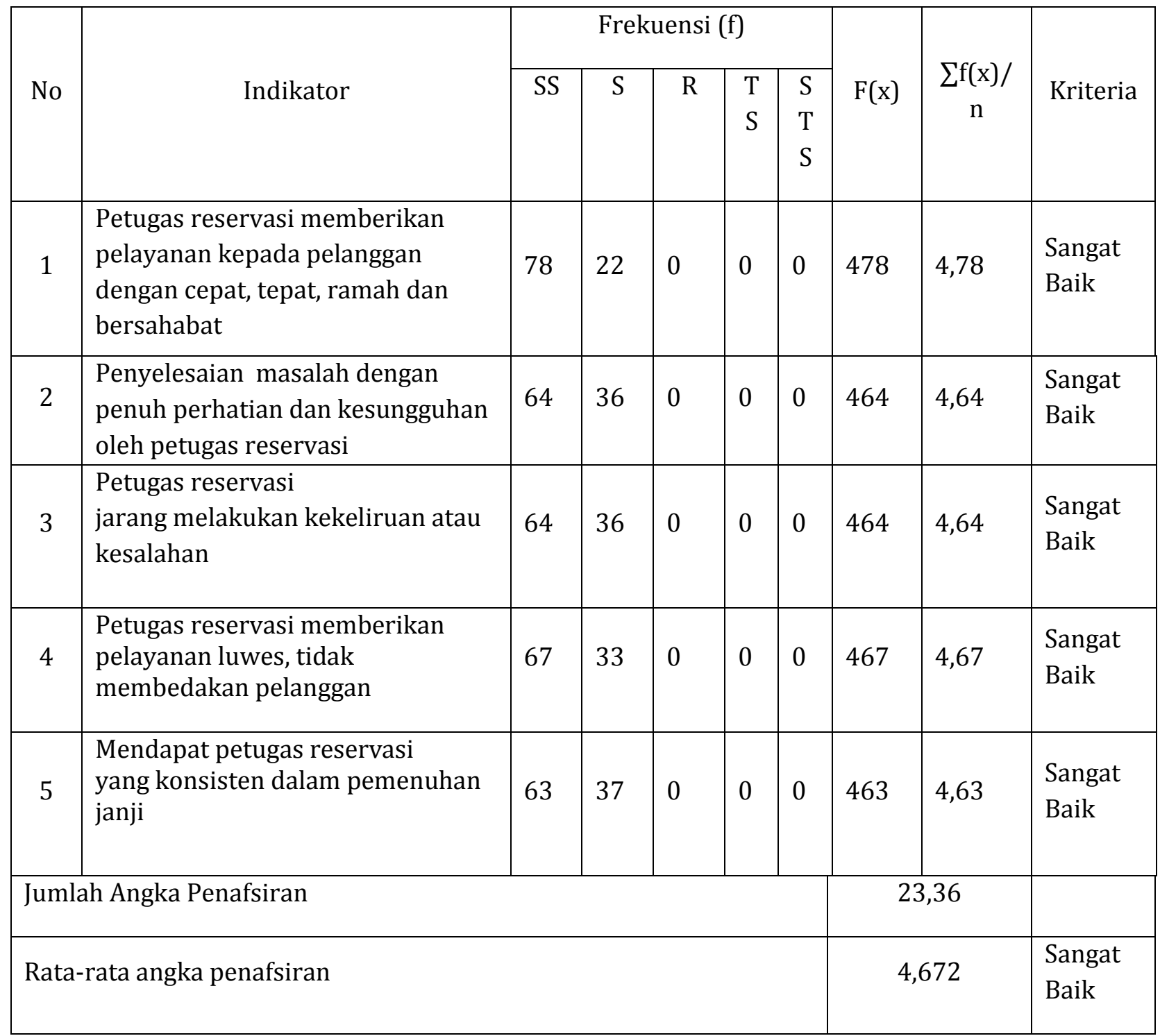

Sumber: Hasil penelitian 2014 
Berdasarkan hasil penelitian, mayoritas responden sebanyak 78 responden (78\%) sangat setuju petugas reservasi memberikan pelayanan kepada pelanggan dengan cepat, tepat, ramah dan bersahabat. Ini dibuktikan angka penafsiran 4,78 pada kriteria sangat baik. Sesuai dengan pernyataan Tjiptono (2006), komunikator mampu memberikan pelayanan dengan segera, akurat dan memuaskan.

Lima indikator variabel empati yakni pemberian perhatian kepada pelanggan, jam kerja yang cukup, pengertian terhadap kebutuhan pelanggan, aktif berkomunikasi dan sangat paham karakteristik pelanggan (Tabel 7).

Tabel 7. Tanggapan Responden tentang Variabel Empati

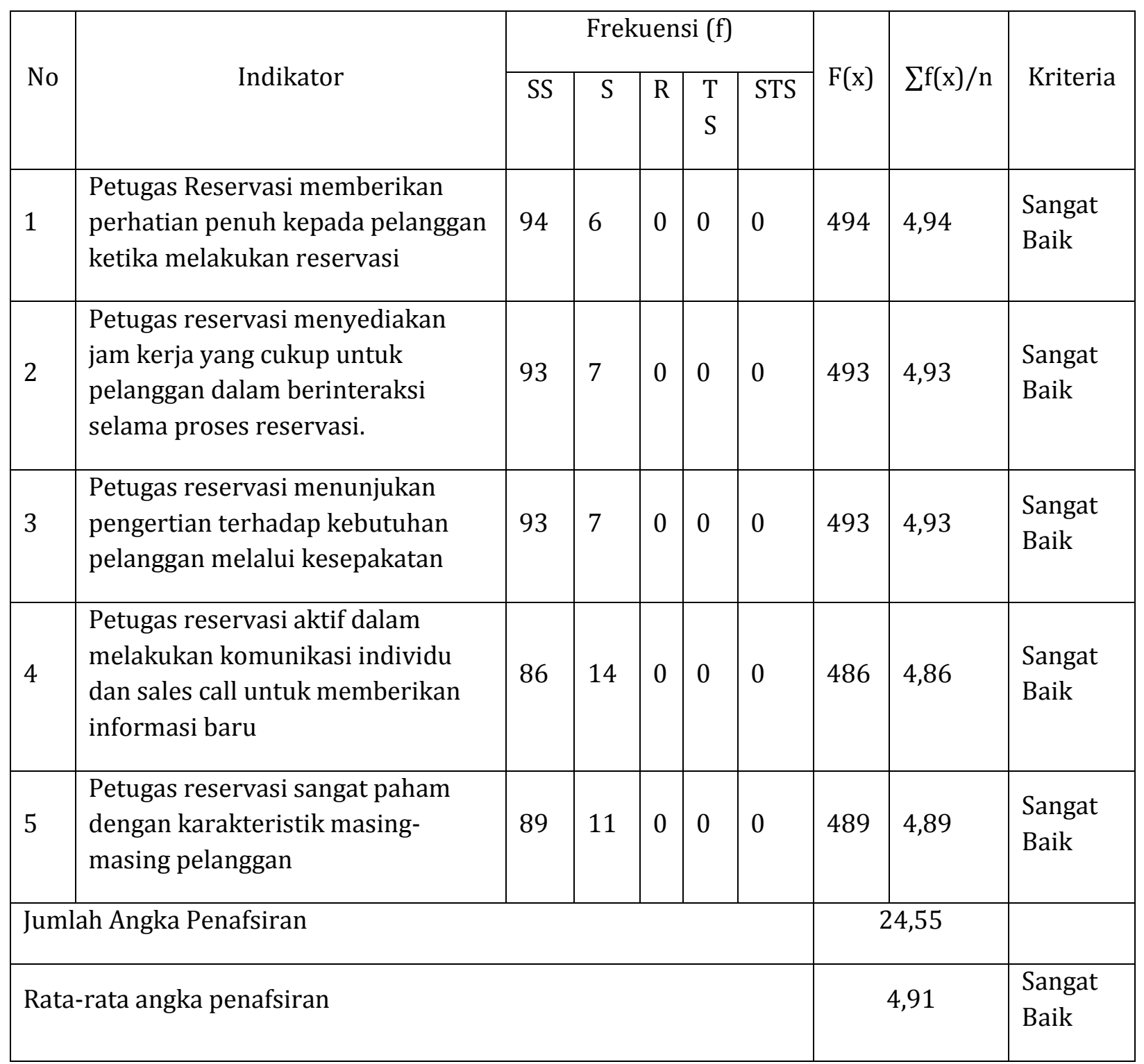

Sumber: Hasil penelitian 2014

Berdasarkan hasil penelitian, mayoritas responden sebanyak 94 responden (94\%) sangat setuju petugas reservasi memberikan perhatian penuh kepada pelanggan ketika melakukan reservasi. Hal ini dibuktikan dengan angka penafsiran yang diperoleh sebesar 4,94 dan berada pada kriteria sangat baik. Sesuai dengan pernyataan Tjiptono (2006) komunikator memberikan perhatian pribadi kepada pelanggan.

Petugas reservasi mampu untuk berkomunikasi dan berhubungan dengan baik 
12 | N Nuraeni, Sukarelawati dan M Fitriah

dan dapat memenuhi kebutuhan yang diperlukan oleh pelanggan selama proses reservasi berlangsung.

Selanjutnya dari variabel daya tanggap diukur dengan lima indikator yakni petugas reservasi menunjukan sikap ingin membantu pelanggan, tanggap dalan menanggapi respon atau permintaan pelanggan, memberikan pemecahan masalah yang dihadapi dengan segera, sigap dalam memberikan pelayanan yang cepat dan dapat mengkoordinasi semua jenis pembayaran dengan baik kepada pelanggan diajukan kepada responden melalui kuesioner yang hasilnya dalam Tabel 8 .

Tabel 8. Tanggapan Responden tentang Variabel Daya Tanggap

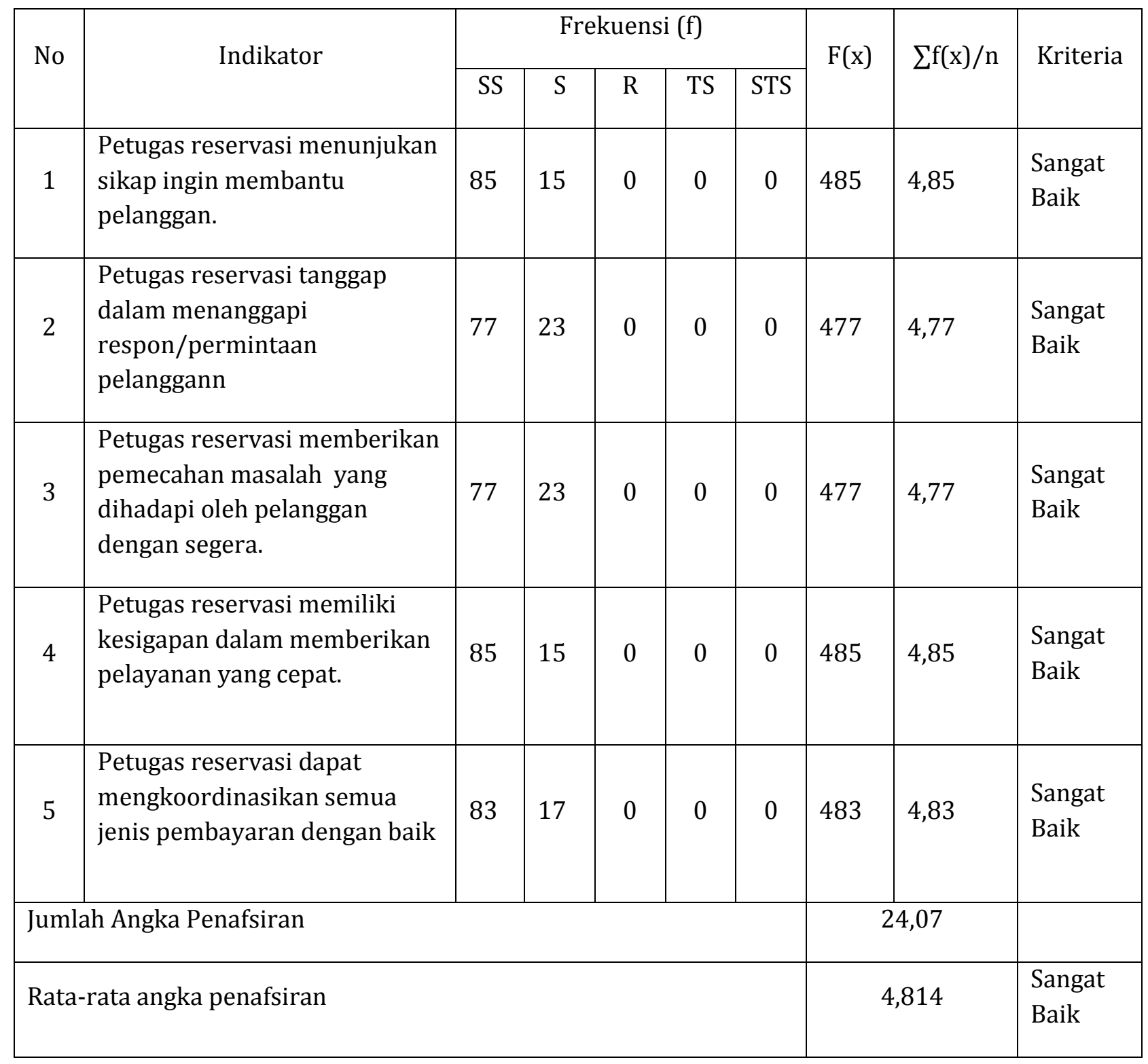

Sumber: Hasil penelitian 2014 
Berdasarkan hasil penelitian, mayoritas responden yaitu sebanyak 85 responden (85\%) menyatakan sangat setuju petugas reservasi menunjukan sikap ingin membantu pelanggan dan petugas reservasi memiliki kesigapan dalam memberikan pelayanan yang cepat. Hal ini dapat diketahui dari angka penafsiran yang diperoleh sebesar 4,85 dan berada pada kriteria sangat baik. Sesuai dengan pernyataan Tjiptono (2006), komunikator membantu dan memberikan pelayanan dengan tanggap kepada komunikan. Petugas reservasi melayani pelanggan, membantu dan menolong pelanggan serta menanggapi permintaan dari pelanggan selama melakukan kegiatan reservasi.

\section{Hubungan Antara Kredibilitas Komunikator dengan Kepuasan Pelanggan}

Tabel 9. Hubungan Kredibilitas Komunikasi Petugas Reservasi dengan Kepuasan Pelanggan

\begin{tabular}{llll}
\hline \multirow{2}{*}{ Kredibilitas } & \multicolumn{2}{c}{ Kepuasan Pelanggan } \\
\cline { 2 - 4 } & \multicolumn{2}{c}{ Keandalan } & \multicolumn{2}{c}{ Empati } & Daya Tanggap \\
\hline Ethos &, $986^{*}$ &, $98^{* *}$ &, $504^{*}$ \\
Pathos &, $196^{* *}$ &, $972^{*}$ &, $997^{*}$ \\
Logos &, $117^{* *}$ &, $509^{*}$ &, $669^{*}$ \\
Kompetensi &, $225^{* *}$ &, $506^{*}$ &
\end{tabular}

Keterangan: ** berhubungan nyata pada taraf $0,01{ }^{*}$ berhubungan nyata pada taraf 0,05

Berdasarkan data pada tabel 9, diketahui hubungan variabel Kredibilitas yang diuraikan dalam beberapa dimensi memiliki hubungan yang nyata pada taraf 0,01 dan 0,05 dengan variabel kepuasan pelanggan. Berikut ini penjelasan untuk setiap indikator penelitian.

Variabel Ethos berkorelasi positif dengan variabel keandalan, empati dan daya tanggap. Hal ini dapat diketahui dimana responden puas terhadap kekuatan persuasif yang dimiliki oleh petugas reservasi. Responden merasa puas karena ucapan-ucapan atau informasi yang disampaikan oleh petugas reservasi selama berinteraksi dengan responden pada saat melakukan reservasi merupakan informasi yang dapat dipercaya.

Variabel pathos berkorelasi positif dengan variabel keandalan, empati dan daya tanggap. Pada variabel empati, Responden merasa puas terhadap kekuatan komunikasi yang dimiliki oleh petugas reservasi dalam hal mengendalikan emosi responden dengan baik. Menurut penilaian responden, kepuasan diperoleh karena petugas reservasi berhasil memberikan solusi yang baik dalam menyelesaikan masalah selama proses reservasi.

Variabel Logos berkorelasi positif dengan variabel keandalan, empati dan daya tanggap. Hal ini dapat terlihat dari jawaban responden yang menyatakan puas terhadap argumentasi yang diberikan serta kata-kata dari petugas reservasi bersikap yang selalu membantu pelanggan, sigap, tanggap dan cekatan dalam memberikan respon/permintaan dari pelanggan serta pemberian solusi atas masalah yang dihadapi oleh pelanggan selama proses reservasi.

Variabel Kompetensi berkorelasi positif dengan variabel keandalan, empati dan daya tanggap. Dalam hal ini pelanggan merasa puas terhadap penguasaan yang dimiliki oleh petugas 
reservasi dalam memberikan jawaban dan dapat memberikan solusi dengan tepat. Petugas reservasi juga dapat mengkoordinasi semua jenis pembayaran yang dilakukan oleh pelanggan dengan sangat baik.

\section{KESIMPULAN DAN SARAN}

\section{Kesimpulan}

Penelitian ini memperoleh kesimpulan sebagai berikut:

1. Kredibilitas komunikator (petugas reservasi) Rancamaya Golf and Country Club dikaji melalui 4 (empat) Variabel yaitu Ethos, Pathos, Logos dan Kompetensi.

a. Variabel Ethos, sebanyak 80 responden $(80 \%)$ menyatakan sangat setuju mendapatkan informasi yang lengkap dan terperinci dengan angka penafsiran 4,8.

b. Variabel Pathos, sebanyak 94 responden (94\%) menyatakan sangat setuju petugas reservasi dapat memberikan solusi yang baik dalam menyelesaikan masalah dengan angka penafsiran 4,94.

c. Variabel Logos, sebanyak 85 responden $(85 \%)$ menyatakan sangat setuju petugas reservasi berkomunikasi secara interaktif dengan pelanggan ketika menyampaikan informasi dan petugas reservasi memberikan argumentasi yang baik dalam menjawab pertanyaan responden dengan angka penafsiran 4,85.

d. Variabel Kompetensi yang terdiri dari lima indikator, sebanyak 96 responden $(96 \%)$ menyatakan sangat petugas reservasi menyampaikan informasi kepada pelanggan dengan penuh percaya diri dengan angka penafsiran 4,96.

2. Kepuasan pelanggan Rancamaya Golf and Country Club dikaji melalui tiga variabel yaitu keandalan, empati dan daya tanggap.

a. Variabel Keandalan, sebanyak 78 responden $(78 \%)$ menyatakan sangat setuju petugas reservasi memberikan pelayanan kepada pelanggan dnegan cepat, tepat, ramah dan bersahabat dengan angka penafsiran 4,78.

b. Variabel Empati, sebanyak 94 responden $(94 \%)$ menyatakan sangat setuju petugas reservasi memberikan perhatian penuh kepada pelanggan dengan angka penafsiran 4,94.

c. Variabel Data Tanggap, sebanyak 85 responden $(85 \%)$ menyatakan sangat setuju petugas reservasi menunjukan sikap ingin membantu pelanggan dan petugas reservasi memiliki kesigapan dalam memberikan pelayanan yang cepat dengan angka penafiran 4,85.

3. Kredibilitas petugas reservasi dengan kepuasan pelanggan menunjukan adanya hubungan yang erat dan positif, yang ditunjukan dengan nilai 0,79211 .

\section{Saran}

Berdasarkan penelitian yang telah dilakukan, maka Penulis menyampaikan saran sebagai berikut:

1. Dari segi Ethos, petugas reservasi diharapkan dapat meningkatkan $s$ pengetahuannya tentang Golf Rancamaya sehingga setiap informasi yang dibutuhkan oleh pelanggan tentang Golf Rancamaya dapat disampaikan dengan baik dan jelas oleh petugas reservasi.

2. Dari segi Pathos, petugas reservasi hendaknya meningkatkan tata cara berbicara dengan tutur kata yang lebih baik kepada pelanggan.

3. Dari segi Logos, dalam menyampaikan informasi kepada pelanggan, petugas reservasi harus yakin dengan informasi yang disampaikannya dan memberikan pelayan yang cepat serta cekatan kepada pelanggan pada saat melakukan reservasi. 


\section{DAFTAR PUSTAKA}

Cangara H. 2007. Pengantar Ilmu Komunikasi. Jakarta: PT. Raja Grafindo Persada.

Hasibuan, Malayu. 2001. Manajemen Sumber Daya Manusia. Jakarta: BumiAksara.

Kotler P dan A.B Susanto. 2000. Manajemen Pemasaran di Indonesia, Analisis Perencanaan Implementasi dan Pengendalian. Jakarta: Salemba Empat.

Tjiptono F. 2004. Manajemen Jasa, Andi. Yogyakarta.

2006. Pemasaran Jasa. Malang: Bayumedia Publishing.

Venus A. 2004. Manajemen Kampanye Panduan Teoritis dan Praktis. Bandung: Simbiosa Rekatama Media.

Wells WD dan Prensky D. 1996. Consumer Behaviour. New York: John Wiley \& Sons. 